\title{
The binding character of contracts \\ - causa and consideration.
}

\author{
Matthias E. Storme*
}

From: Towards a european Civil Code (red. A.S. Hartkamp, M.W. Hesselink, E.H. Hondius), Second revised and expanded edition, Kluwer / Ars aequi 1998, 239-254

\section{CONTENTS}

1. Introduction.

2. The binding character of contracts or promises

2.1. The scope of the freedom to contract s.s.

2.2. The minimum core of common rules and a (re)formulation of the problem

2.3. Cause, consideration and the "mere agreement" rule.

2.4. Theoretical background and some lessons to be learned from social sciences.

2.5. The hidden requirements - cause and consideration.

2.6. Evaluation

2.7. Sufficient agreement, "object" and indeterminate terms.

3. Integrating the different sources for the construction or determination of contractual obligations

3.1. Different sources of contractual content

3.2. Defining bona fides.

4. The tendency to restrict invalidity in favour of application of the rules on performance and non-performance

4.1. Promises losing their "causa".

4.2. Validity to be determined at the time of concluding a contract.

4.3. Impossibility from the outset is not an invalidity

4.4. Unlawfulness from the outset.

4.5. Abstraction of promises

\footnotetext{
* Matthias E. STORME

Hoogleraar at the Katholieke Universiteit Leuven and Universiteit Antwerpen. Secretary of the Commission on European Contract Law (since 1992). Executive Editor of the European Review of Private Law. Advocate at the Brussels Bar.

FIELD OF SPECIALISATION : Law of obligations, property law, european and comparative law
} 


\section{Introduction.}

The subject of this contribution lies somewhere between formation, interpretation and validity. Let me first explain why these subjects are so closely linked.

First of all, it is possible to devise but very few rules on the validity of contracts in general. It is rarely appropriate to refer to the validity of contracts without explaining what type of obligations have been affected - i.e. created, modified or terminated - by the contract. It is therefore more sensible to examine what types of obligation, and what terms, may be validly created, modified and/or terminated by means of a contract (which will provisionally be defined as a transaction between the parties), as well as the conditions in which they may do so. Therefore this contribution will be explicitly restricted to "obligational contracts" (contracts dealing with obligations) and will not deal with agreements where they have direct implications for the property relationships involved (e.g. the transfer of property or creation of limited rights of ownership).

Similarly, it is very difficult to separate the question of the validity of contracts, which ultimately comes down to the question of the binding nature of obligations created by contracts from the issue of the formation of contracts (and the creation of obligations thereunder). Not only the matters which affect the consent of the parties, which will be dealt with elsewhere in this book, but also the question whether consideration and/or acceptance is necessary on the part of the creditor for the undertaking to be binding, demonstrates the close relationship which exists between those two subject. Even the question of unfair contract clauses is linked to that of formation, since the rules tend to differentiate between standard clauses and individually negotiated clauses.

I will therefore start (under 2.) with the question of the requirements for the legally binding character of agreements and / or promises.

\section{The binding character of contracts or promises}

\subsection{The scope of the freedom to contract s.S.}

a) Under what conditions, and to what extent, are expectations created by a promise or a commitment ${ }^{1}$ made by another party protected by law, especially where they are not matched by voluntary performance?

All European legal systems do recognize the freedom of persons which have the capacity to act at law in order to regulate their (mutual) regal relationships - subject to certain

1 "Commitment" is the term used by J. KÖNDGEN, in, inter alia "Reconstructing promissory obligation : a socio-legal analysis", 11. Tel Aviv University Studies in Law 1992, (151) 154 ff., esp. 160, precisely in order to broaden the concept of promise in order to include any communicative behavior which brings about some sort of obligation. 
restrictions, to be discussed later - by means of undertakings (promises and/or contracts) which will be binding upon them (this binding nature being subject to more specific rules on non-performance, termination, etc). Would it therefore not be sufficient to embody this principle in a European Code of Contract Law, merely adding certain specific rules on matters affecting the consent of the parties and the capacity to act at law, as well as a general rule on the limits of the freedom to contract, these limits being expressed in terms of "illegality and/or immorality" ?

Such an approach would, in my opinion, soon prove to be inadequate. A mere glance at the rules of domestic law and the proposed uniform principles relating to defects of consent, particularly those on mistake, shows that the question of the formation and validity of contracts cannot be reduced to a mere meeting of the minds within some general limits traced by law. The many cases which concern the contractual liability for obligations not truly agreed upon (obligations arising from reliance, clauses supplemented by mandatory and even non-mandatory rules, etc.) in my opinion only serve to increase the number of question marks on this issue.

In addition, some elementary but unbiased reflection on this question leads to the conclusion that the freedom to contract as such - as a principle of public law rather than private law - cannot by itself explain why parties are no longer free to change their minds unilaterally, whereas the binding nature of promises or contracts will be of no use as long as long as the parties fail to change their minds. Thus we need to draw a distinction between, on the one hand, the problem of the freedom of the parties in relation to the public authorities and/or third parties ${ }^{2}$, and, on the other hand, the question of their mutual(contractual) liability As long as legal rules do nothing more than rendering certain promises or contract clauses unenforceable, without prohibiting their performance, it is not the hallowed principle of the freedom to contract which is at stake, but precisely the opposite, namely subjecting one of the parties to a power which the other party claims to exercise over the former. Such powers, if they are to be allowed or recognized by law, must be legitimised by other means than merely relying upon the freedom to contract.

\subsection{The minimum core of common rules and a (re)formulation of the problem}

On the other hand, it is not necessary to carry this reflection to the ultimate conclusion of denying promises any specific legal significance whatsoever, and of allowing the law of contracts to be subsumed into the mainstream law of torts. We must certainly not elevate the distinction between contract and tort, or the parallel distinction between a positive (expectation) interest and negative (reliance) interest to the status of an absolute principle ${ }^{3}$;

2 The problems which concern the involvement of specific third parties in contracts - e.g. the actio Pauliana - are not dealt with in this contribution.

3 In my opinion, the attempts to draw a body of general principles of contract law, such as the Unidroit Principles of International Commercial Contracts (PICC) or the Principles of European Contract Law (PECL), are too much based on the "classical" theory of contracts Comp. the criticism made by, inter alia, J.H. van ERP, "Europees privaatrecht in 
nor is it necessary to do so in order to establish that it is at least useful to "stake out an enclave within the general domain of tort ${ }^{4}$ in the sense of establishing a separate set of rules on the obligations arising out of promises and the specific content of such obligations in legal terms. All European legal systems identify in at least some cases involving contracts, or in certain types of contract, a contractual liability which cannot be completely reduced to the rules of tort law, and where the test of liability is not purely the enforcement of a "negative interest".

All these systems have in common that contractual liability, or, if you prefer, the binding nature of contractual obligations, is to a certain extent - subject to restrictions based on the public interest or on the interests of third parties - based on a mixture of a certain notion of autonomy and a certain notion of legitimate expectation or of reliance, although opinions may differ on such matters as the conditions of legitimacy of the expectation or reliance 5 . However, these differences do not necessarily follow national lines, and can also be found among leading authors operating within the same legal system.

\subsection{Cause, consideration and the "mere agreement" rule.}

As to our question under what conditions, and to what extent, expectations created by a promise or a commitment made by another party are protected by law, both "Principles" have a seemingly simple answer. In order to exclude the need for consideration, cause, performance (in the so-called "real" contracts) or formality as a general requirement for the validity of contracts, the Unidroit Principles of International Commercial Contracts (PICC) and the Principles of European Contract Law (PECL) ${ }^{6}$ expressly state that there is no further requirement for the formation of contracts :

"A contract is concluded, modified or terminated by the mere agreement of the parties, without any further requirement" (PICC Art. 3.2.)

c.q.

"A contract is concluded if a) the parties intend to be legally bound and b) they reach a sufficient agreement,without any further requirement" (Art. 2:101 PECL) ${ }^{7}$.

Further, the PECL have thus laid down the principle that "A promise which is intended to

ontwikkeling", in : Themis en Europa, p. (61) 65.

4 This expression is used by G. GILMORE, The death of contract, Ohio State University, Columbus 1974, p. 87.

5 Roughly speaking, these vary from, on the one hand, the requirement of an equivalent quid pro quo, to, on the other hand, the mere acceptance of the promise in the reasonable belief that a statement or conduct constitutes a promise of a certain tenor made to him.

6 The PECL is cited in its first full version, to be published early 1998. The Articles are numbered with a : (e.g. 2:101) instead of a . (e.g. 5.101) to avoid confusion with the 1995 edition of Part I.

7 Compare Art. 29 (1) CISG : "A contract may be modified or terminated by the mere agreement of the parties". 
be legally binding without acceptance is binding" (Art. 2:107 PECL). Present-day law, including current attempts at enacting a European private law, thus applies - at least in theory - as the sole standard to determine which expectations of promisees are protected and which ones not the intention to be legally bound, which is to be concluded from the promisor's statement and conduct as they might reasonably appear to the promisee (cf. Art. 2:102 PECL : "as they were reasonably understood by the other party").

Still, in my opinion, things are not as simple, and I'll try to demonstrate it.

\subsection{Theoretical background and some lessons to be learned from social sciences.}

Let me start with the foundations given to the binding force of promises. As has been stated earlier (cf. No. 3 in fine), the fact of subjecting the promisor / debtor to the power of the promisee / creditor has to be legitimised by other means than simply invoking the freedom of contract, since the freedom to contract does not in itself explain why the expectations of the disappointed party will be protected if the other party changes his mind. Obviously, the autonomy of the parties plays an important role, but not, perhaps, in its usual sense. Since the law is concerned with relationships between persons, the ideas of autonomy and the (protection) of reliance or legitimate expectation must also be viewed in a relational manner. The required autonomy is the autonomy on the part of the promisor, but it must be seen in relation to the promisee. The question is not so much whether the will of the promisor was defective or not, but whether the promisee did respect the right of selfdetermination of the promisor and did not unduly influence it. Since I have dealt with this subject elsewhere ${ }^{8}$, I will not elaborate on this idea here. However, I will give some thoughts on the other element, being its reverse, namely the element of "confidence" (legitimate expectation or reliance).

The "confidence" required is the confidence on the part of the promisee, but this must also be seen in a relational manner. Contract law deals with the protection of legitimate expectation caused by the conduct of the other party, regardless of the actual detriment caused by the reliance on these expectations and conduct ${ }^{9}$. This is legitimate to the extent that it is reasonable for the promisee to entertain such expectations, to expect performance (or expectation damages) from the promisee. Is the mere intent (or appearance of intent) of the promisor really the best criterion to determine whether the promisor did sufficiently cause the promisee to rely on the promise, to expect its performance?

8 "De bindende kracht van de overeenkomst", in : Beginselen van vermogensrecht, BW-krant jaarboek 1993 (M.E. Franke, J.P. Jordaans, J.M. Smits \& W.L. Valk, Eds.), Gouda Quint, Arnhem 1993, 117 ff.; "Rechtszekerheid en vertrouwensbeginsel in het Belgisch verbintenissenrecht", Preadvies Vereniging voor de Vergelijkende Studie van het recht in België en Nederland 20-11-1997, in Vertrouwensbeginsel en rechtszekerheid in België, Tjeenk Willink 1997, p. 1-67.

9 Restricting contractual protection to cases of actual detrimental reliance would constitute a strong incentive to overrely. Compare J. KÖNDGEN, in 11. Tel Aviv University Studies in Law 1992, (151) 187-188. 
To take the appearance of the intention to be bound as the criterion for the reasonableness of these expectations presupposes the anthropological view that men who promise and carry out their promises are not primarily prompted by a multitude of egoistic and altruistic motives, such as the obtention of material benefits, or the opportunity to do so, the stabilisation of mutual relationships, the granting of rewards, the fact of earning gratitude, praise, honour, etc., but primarily by one single motive, i.e. to affirm one's identity by living up to previous representations made of one's self. Certainly, the lastnamed motive is an important human motive ${ }^{10}$. Further, it provides us with the best possible way of legitimising the classical doctrine of contracts ${ }^{11}$, and does so far better than the rather nonsensical traditional explanations. However, it would certainly be going too far to consider it to be the main, or even the sole, reason for issuing promises and for carrying them out. However important the quest for identity may be to human beings, it will not continue to prompt him to conform to his representation of himself if the fact of his carrying out his promise is not sustained by any reciprocity. Reciprocity must, however, be understood in a much wider sense than that which is used under the traditional doctrine of consideration ${ }^{12}$.

\subsection{The hidden requirements - cause and consideration.}

A closer look at the actual contract law of the different jurisdictions shows that a mere promise with the intention to be legally bound, without any other element of formality or consideration, hardly ever constitutes an adequate reason for enforcing performance, regardless of any actual reliance on it. In the German-based legal systems, an additional requirement was constituted by (1) the requirement that the - gratuitous - contract be in written form, as in the case of donations, and (2) the need to accept the promise, even in the case of unilateral contracts, this being a requirement which can not be explained if the intention to be bound constituted the sole criterion for the binding nature of a promise ${ }^{13}$.

In the French-based legal systems, gratuitous contracts were traditionally enforceable only if they were surrounded by certain formalities (e.g. donation) or if its performance had already started (manual gift inter vivos, real contracts). Such contracts are indeed lacking a

10 An interesting testimony can be found in Hannah ARENDT, The Human Condition, New Yourk Double Day 1959, p. 237 : "Without being bound to the fulfilment of promises, we would never be able to keep our identities; we would be condemned to wander helplessly and without direction in the darkness of each man's lonely heart, caught in its contradictions and equivocalities - a darkness which only the light shed over the public realm through the presence of others, who confirm the identity between the one who promises and the one who fulfils, can dispel".

11 I have been assisted enormously in developing my awareness of this by J. KÖNDGEN, in 11. Tel Aviv University Studies in Law 1992, (151) esp. 161.

12 KÖNDGEN, Ibid. , esp. 176 ff.

13 Cf. in particular G. GORLA, "Il dogma del consenso", Rivista di diritto civile, 1956, 923, also in : Diritto comparato e diritto comune europeo, Giuffré Milano 1981. 
"cause" in the strict sense of the word - at least when the word is used in its first meaning or function.

Certainly, the notion of cause has been criticized and is often considered useless. The main problem with the notion of "cause", as used mainly in French-based legal systems, is, however, not its uselessness, but the confused manner in which several functions have been merged into one concept - the majority of these aspects concerning private interests but some of which also involve considerations of public policy. Roughly speaking, it is possible to distinguish between at least three different functions of this notion in the law of obligations where this notion is regarded as a requirement for the validity of a contract (the fourth function, which concerns the transfer of property, is not discussed here $)^{14}$. The first function is discussed here, the other ones further down.

The first function of this notion consists indeed of distinguishing binding promises or commitments on the one hand, and unenforceable ones on the other hand. The term "binding" has to be understood as creating a liability which may exceed the scope of tortious liability (in traditional terms : a liability according to the expectation interest which may possibly exceed a liability according to a mere reliance interest). Viewed in this light, the term "cause" is a "causa obligationis", a reason for conferring a claim on the promisee, and must be vested with the promisee.

This function more or less corresponds to the "consideration" under the anglo-american common law : a promise without consideration on the side of the promisee is normally only binding if surrounded by certain formalities (deed) ${ }^{15}$. Although "consideration" is considered as an issue relating to the formation of contracts rather than to their validity, an examination of the common law doctrine on this subject can reveal to us the close relationship between problems which have traditionally been treated as totally separate issues on the Continent, such as cause, form and acceptance.

Unlike consideration, the concept of cause has been extended, and therefore diluted to such an extent - whether deliberately or by misunderstanding - that it seems to have disappeared altogether from the continental legal systems as an actual requirement as distinct from consent and acceptance.

\subsection{Evaluation}

I think we have to question these traditional doctrines as well as the modern conception of the Principles, which is doing away with them. I do not consider the (serious) intention to be legally bound as being an appropriate criterion for distinguishing between binding and non-binding promises. Further, the requirement of acceptance, which is added by certain

14 This passage owes so much to the analysis made by G. GORLA, Il contratto, that there is probably little point in giving more specific references to his work.

15 For a general comparative overview of the different "indications of seriousness of the promise”, see H. KÖTZ, Europäisches Vertragsrecht, Mohr Tübingen 1996, § 4. 
legal systems, is even completely useless. Acceptance adds nothing decisive to the extent to which the other party intends to be legally bound, to the reasonable appearance assumed by the promise, or to the degree of reliance which must be protected. It is a very poor criterion by which to draw the distinction between binding and non-binding promises, and it is good that it has disappeared from the PECL (see the abovementioned art. 2:107 PECL).

Further, the traditional doctrines are certainly not as useless as often stated. Is not the price to be paid by the promisee, i.e. the reliance which is bargained for, the most convincing reason for keeping the promisor to his promise ? And, in the absence of such a reliance bargained for, is there a better criterion available than the fact that the promisee is in possession of a promise which is materialised or realised, such as a deed supplied to him, or the delivery of the thing promised, as is the case in the manual gift inter vivos or gratuitous loan (loan without interest)?

However, legal development has shown that the traditional standards of cause and consideration are too narrow ${ }^{16}$. Therefore, the ideas which underlie these concepts must be taken into account, not by imposing additional requirements for a promise in order to be binding, but rather by taking them into account when interpreting promises and determining their contents and conditions. In order to do this, it is necessary to see that we cannot separate completely the question whether a binding contract has been concluded (question of formation and validity) from the question what "binding character" means in every case (determined by the rules on contents and non-performance). Such a separation obscures that there is no such thing as the binding character of the contract, but that there exist only various degrees to which a contract binds the parties. The latter depend, inter alia, on the benefit, or disadvantage (detriment) or reciprocity sensu lato of the transaction. No system of contract law enforces contracts without consideration with the same degree of severity as reciprocal promises, especially if such contracts have not been concluded in the course of business ${ }^{17}$. The interpretation of such gratuitous promises is also different : it is often accepted that the decisive motive of such promises constitutes an implied term, even if it was not the motive of the promisee - in reciprocal contracts, this must be a motive common to both parties. The measure of their enforcement is also different and is probably closer to that which prevails under the law of torts (namely negative interest instead of positive interest). Exemption clauses will be judged more liberally in relation to gratuitous services. Reciprocity certainly plays a part in the balance of rights and obligations of the parties, which may not be disturbed to the consumer's detriment contrary to the requirement of good faith (cf. Art. 3 EC Directive on unfair terms in consumer contracts) ${ }^{18}$. Simplifying,

16 See the overview by H. KÖTZ, Europäisches Vertragsrecht, $\S 4$.

17 See G. GORLA, Le contrat dans le droit continental et en particulier dans le droit français et italien, Institut universitaire d'études européennes Torino 1958, § 11-12; recently A.C. van SCHAICK, "Affectionis causa", in In het nu wat worden zal. Opstellen Schoordijk, Kluwer Deventer 1991, 223 ff.

18 Although "assessment of the unfair nature of the terms shall relate neither to the definition of the main subject matter of the contract nor to the adequacy of the price and remuneration, 
we could say that there is an intermediate category of commitments, mainly consisting of gratuitous contracts or promises. In the absence of something "more" than mere agreement, such as reciprocity or formality, the agreement has not the same degree of bindingness as in case of reciprocal agreements.

The standard of "seriousness" of intent thus has to be corrected, not by imposing additional requirements for a promise in order to be binding, but by giving weight to elements such as reciprocity when interpreting promises and determining their contents and conditions. Rules of interpretation such as the one contained in Article 2:102 PECL, which states that a party's intention must be deduced from that party's statements or conduct as they were reasonably understood by the other party, make this possible. Indeed, it must be reasonably apparent to any promisee that something like an intention to be legally bound does not exist as an abstract concept, but is invariably conditioned by the type of transaction and the relevant circumstances, especially the degree of reciprocity involved. It is also reasonably apparent to the promisee that certain types of statement and conduct, especially if it assumes a written form, indicate a more serious intention to be legally bound than others.

\subsection{Sufficient agreement, "object" and indeterminate terms.}

Let me finish the discussion on the objective conditions for the recognition of a binding contract or promise with the second element put forward by the principles, namely "sufficient" agreement.

Here, again, French-based legal systems use a concept, namely that of the "object" of a contract, which is considered to constitute a requirement for the validity of a contrarct, but in fact, like the notion of "cause", a mishmash of various issues, most of which can hardly be regarded as being fundamental requirements for the validity of a contract ${ }^{19}$. Also, like the cause, the object of a contract and the object of the obligations arising from it (or altered or terminated by it) have also become mixed up in this concept. The notion of object plays a role in several problems which are discussed infra 4. It is also used as a concept to check the sufficient determination of terms; according to art. 1129 C.C., the object of the obligation has to be "determined". According to case law, it is sufficient that the subjectmatter can be determined; the question is whether such determination can take place by one of the parties. What is needed is indeed not a separate requirement for the validity of a contract or obligation, but a set of rules laying down the circumstances in which the terms

ont the one hand, as against the services or goods supplied in exchange, on the other (...)" (art. 4 (1) of the Directive) (Compare e.g. Art. 6:231 NBW; ABGB § 879, 3; German AGBGesetz § 8 ), the unfairness of any other contractual terms "shall be assessed taking into accout the nature of the goods or services (...) and by referring to (...) all the other terms of the contract (...)" (art. 4 (2) of the Directive), thus taking into account the price or the remuneration.

19 Once again, I am indebted for this view to G. GORLA, "La teoria dell'oggetto del contratto nel diritto continentale (civil law)", JUS 1953, 289 ff. Compare also ZWEIGERT / KÖTZ, An introduction to comparative law, II, p. 7. 
can be determined by objective standards and the methods for determining a term which can be lawfully chosen by the contracting parties. As to further developments, for brevity sake I'm referring to $\S 3$ of H. Kötz' Europäisches Vertragsrecht, dealing with this in detail. Some ideas and references to the PECL can also be found in my chapter in the first edition of "Towards a european civil code".

\section{Integrating the different sources for the construction or determination of contractual obligations}

\subsection{Different sources of contractual content}

Before turning to specific invalidities, which relate to the contents of contracts, we have to giev some attention to the mechanisms by which certain types of contractual content can be inserted in the contract or, on the contrary set aside.

This is the question of the relationship between the various elements which are traditionally accepted as determining the contents of a contract, i.e. clauses, implied intentions, custom and practice, statutory provisions, and reasonableness and/or equitableness $^{20}$. Whether we apply a broad or a narrow view of what contitutes interpretation $^{21}$, the contents of a contract are invariably determined by combining, or "integrating", these different sources, usually on the basis of a certain hierarchy between them. When reassessing the prospect of a common European system of contract law, we should ask the question whether it is possible to devise a principle - or rather a perspective - on the basis of which the integration of these various sources of the contents of a contract can be understood.

Here again, the traditional view is that to determine the contents of a contract, one should start from the interpretation of the statements and conduct of the parties in the psychological sense of the term, namely from the intention of the parties to be legally bound as expressed in these statements and conduct. However, such a principle will be even less capable of explaining the manner in which the contents of contracts are determined than it was capable to explain its binding character "by mere agreement of the parties" (cf. supra, 2). The intention of the parties can only explain a small proportion of the contents of a contract (these contents include the rules on performance and nonperformance, the implied terms and conditions, etc.). It provides no explanation for the mandatory rules which protect private interests of the parties (usually the so-called weaker party) and only gives a fictitious or artificial idea of non-mandatory rules (by explaining

20 Most, or all, of these elements are found in the various domestic or international codifications. Cf. e.g. Art. 7-9 CISG, Art. 1:105, 1:201-1:202, 1:302 and 6:102 PECL, Art. 1135 French and Belgian Code Civil.

21 The question of interpretation in a narrow sense is not further discussed as such here. In the first edition of Towards a european civil code, I have discussed the question as to what intention of the parties is relevant in cases where that intention is not entirely shared by both parties. 
them as an expression of the implied intention of the parties).

Certainly, on a very broad range of human activities, the parties to a contract are, in principle, free to regulate their mutual relationships, in the sense that the public authorities will not interfere as long as the parties still agree, except by virtue of certain rules and restrictions dictated by the requirements of public policy and public morality. They are free to carry out their promises and other acts claimed by the other party. But here again, this freedom to contract fails to solve the problems which arise where parties no longer are in agreement ${ }^{22}$. It is nonsensical to claim that it is the notion of autonomy of the will which prompts us to compel a person to perform that which he once intended, but now no longer wishes, to perform. The basic issue of contract law is to determine what expectations of the parties have to be protected by law, and to what degree they must be thus protected, when they are not being voluntarily fulfilled. Once again, the intention of the parties to be (legally) bound is in my opinion an unsatisfactory criterion for establishing this. In reality, our law of contracts - and our private law in general - does not decree that one must in all circumstances be as good as one's word, but rather that one must act as a reasonable man, taking into account the legitimate interests of the other party; these two criteria are often, but not always, the same. The expectation which is protected by law, and therefore also the contents of a contractual obligation, is precisely that the other party should act as a reasonable man.

This prospect on the law of contracts, and on private law in general, has, ever since the heyday of Roman law, been symbolized by the notion of bona fides (good faith) - or, in its procedural expression, the exceptio doli generalis ${ }^{23}$. Therefore good faith is not so much a rule on the same level as other rules, but rather the principle on the basis of which the various elements enabling us to determine the contents of contractual obligations need to be integrated. This notion of bona fides is also contained in the PICC and the PECL. A rather far reaching notion of good faith is also implied by the EC Directive on unfair terms in consumer contracts (cf. Art. 3 (1)).

\subsection{Defining bona fides.}

Obviously the fact that the principle of good faith takes precedence over the various

22 Compare in particular G. ROUHETTE, "La force obligatoire du contrat, rapport français", Le contrat aujourd'hui, translated as "The obligatory force of contract in french law", in Contract Law Today. Anglo-French Comparisons.

23 See BECK, "Zu den Grundprinzipien der bona fides im römischen Vertragsrecht", Aequitas et bona fides, Festschrift Simonius, 18 ff.; C. ZEVENBERGEN, Aard en weking der goede trouw in het romeins verbintenissenrecht; F. BAERT, "De goede trouw bij de uitvoerig van overeenkomsten", Rechtskundig Weekblad 1956-57, 487 ff.; L. NANNI, "L'uso giurisprudenziale dell'exceptio doli generalis", Contratto \& impresa 1986, 197 ff.; WENDT, "Die exceptio doli generalis im heutigen Recht oder Treu und Glauben im Recht der Schuldverhältnisse", AcP 1906 II, 1 ff.; R. ZIMMERMANN, The law of obligations. Roman Foundations of the Civilian Tradition, Juta Cape town, 1990, p. 668, 674. 
elements of the contents of a contract tells us nothing yet about the practical meaning of this concept. The object of this concept is precisely not to convey a clear-cut meaning, but to dispel the creeping danger of fossilisation to which the law is always vulnerable ${ }^{24}$. Thus the prevailing trends in society on the concepts of fairness and reasonableness can come into play.

Certainly the prevailing view has been that reasonable behaviour consists of nothing more than keeping to one's word in all circumstances, or at least to keep to one's word in the manner (commonly) intended by the parties. Coming from the pen of Domat, who formulated the rule contained in Article 1134 of the Civil Code, this principle probably translated his Jansenist view that man, as a sinful being, was only capable of receiving divine grace by keeping his promises at all cost. These moralistic views also corresponded to certain trends and needs in society, which was avid for security after a century of civil and religious wars. This conception survived the age of industrialism and capitalism virtually unscathed, although one major change which occurred was the much greater degree of freedom to determine the contents of contracts; the rather extreme view taken of their binding nature reflected an attitude which viewed all contracts as an exercice in riskallocation. This idea remains very much alive today in the rules which govern international commercial contracts, since usually they continue to be viewed as such an exercice.

However, in many respects our anthropological (or social, if you want) perceptions have changed, and with them our interpretation of the notion of good faith. On the one hand, the definition of the price and other subject-matter of contracts for the exchange goods or services has been liberalised to an unprecedented extent - mainly on the account of the development of competition law. On the other hand, the allocation of risks in case of nonperformance is considered to be primarily a matter of collective decision-making. More particularly there is a "growing recognition that the opportunity to change one's mind is itself a valuable right which often outweighs the desirability of holding parties bound to some futur arrangement" 25 . More generally, the idea of the autonomy of the will is changing radically. The basic metaphor used by Grotius, which held a promise to be a partial surrender or alienation of one's freedom ${ }^{26}$, is gradually becoming unacceptable in

24 Compare the resistance by many authors to giving too concrete an expression ('herunterkonkretisieren') of the principle of good faith, e.g. G. TEUBNER, "Die Geschäftsgrundlage als Konflikt zwischen Vertrag und gesellschaftlichen Teilsystemen, zur Fragwürdigkeit ihrer Re-Dogmatisierung", ZHR 1982, 625 ff., and in Alternativkommentar zum $B G B$, "§ 242"; H. SCHOORDIJK, "Typologiseren en moduleren", in Rechtsvinding, 235 ff.; W. van GERVEN \& A. DEWAELE, "Goede trouw en getrouw beeld", in Liber amicorum Jan Ronse, Brussel 1986, p. (103) 111; Comp. H. MERZ, "Die Generalklausel von Treu und Glauben als Quelle der Rechtsschöpfung", ZsR 1961, (335) 344; S. DAVID-CONSTANT, "Des vivants et des morts dans le droit des obligations", Journal des tribunaux 1977, 651.

25 P.S. ATIYAH, The Rise and Fall of the Freedom of Contract, p. 756.

26 H. GROTIUS, Inleidinge tot de hollandse rechtsgeleerdheid, III.1.12. Cf. the Comments made by G. GORLA, "Il potere della volontà nella promessa come negozio giuridico", Rivista di diritto commerciale 1956, I, 18, reprinted in Diritto comparato e diritto comune europeo, 
present-day thought, which is taking the notion of the inalienable nature of fundamental rights much more seriously. The elevated moral notion of the autonomy of the human person is probably better served by a legal system which emphasises the duty to respect the right to self-determination of others, even if they fail to keep their promises, than by a legal system which imposes strict liability for the non-performance of promises.

Clearly, the notion of reasonable behaviour continues to imply that the normal situation is for a person to keep to his word. It remains part of our anthropological perception that a person affirms his identity by living up to the manner in which he has presented himself before, to the image which one has created of oneself; moreover, this idea is well entrenched in both the law of torts and the law of contracts. However, reasonable behaviour cannot be seen to be determined solely by such a quest for identity, and not also by other human motives, such as obtaining material benefits, stabilising mutual relationships, granting rewards, earning gratitude, praise or honour, etc. Many of these motives are considered to be equally reasonable, and law must take that into account.

As a result, the notion of good faith is no longer understood as conveying the simple idea that one should keep to one's word, but rather as a combination of a number of elements or principles to be balanced against each other. The most important of these elements or principles can be summarized as

(a) responsibility for the expectations one has created, not only by making promises, but also by making other types of statement, by conduct, or even by remaining silent, as long as the promisee placed a reasonable interpretation on these elements and did not understand them as an unconditional intention or a creation of strict liabilities;

(b) due respect for the right of self-determination, free from any undue influence;

(c) the maintenance of a degree of proportionality between the advantages and the disadvantages which any action can cause to the parties involved;

(d) determining the rights and obligations of the parties taking into account their reciprocity - to be understood in a broad sense, and thus including elements such as past consideration, goodwill, etc., and not only the reliance bargained for (consideration), and

(e) the fair allocation of risks, taking into account the possibilities of the parties to avoid or shift or spread them. These ideas form the basis of most of the more specific rules of the law of contracts, but the precedence which the notion of good faith has over these rules guarantees the possibility that they might be rebalanced, when the more specific rules will have become inappropriate in the changed social or economic climate. It transforms the system of contract law to a dynamic system, under which the relative value of the various elements need to be assessed continuously, and shifted gradually.

For further developments on the concept of bona fides and its applications (e.g. in the field of general conditions), I'm referring to the chapter on good faith in Towards a european civil code and to Kötz, Europäisches Vertragsrecht.

Giuffré Milano 1981; M. DIESSELHORST, Die Lehre des Hugo Grotius vom Versprechen, p. $34 \mathrm{ff}$. 


\section{The tendency to restrict invalidity in favour of application of the rules on performance and non-performance.}

\subsection{Promises losing their "causa".}

In roman-base legal systems, the notion of causa is generally used (apart from the first described function given to it in French legal systems, described supra 2.) in order to give relevance to certain assumptions made by one or both of the parties which do not give rise to any possibility of avoidance based on mistake in accordance with the relevant rules on mistake. "Causa" in this sense is not the "causa obligationis" (comparable to the notion of consideration), but the cause of the promise (or of any other legal transaction) (the concept is precisely not restricted to acts creating obligations), sought on the part of the promisor. In the French Civil Code, it is expressed by the term "fausse cause". However, the term is not restricted to French-based legal systems, but is also found in provisions such as $\S 812$ BGB.

Originally, it was used only to give relevance to the typical assumption concerning the legal situation or the effects of the act, and the number of causae (Rechtsgründe) was limited : namely, a promise could be made credendi or adquirendi causa (on the assumption that a reciprocal claim or property right would be obtained), solvendi causa (on the assumption that one will be freed from a lawful debt or obligation), in order to guarantee the performance of an obligation assumed to be valid, or donandi causa (assuming no debt or reciprocal claim, except for some expression of gratitude). It was thus able to solve the problem of "erreur sur l'efficacité juridique de la cause". However, where the assumption made relates to facts or to law existing when the promise was made or the contract concluded, it was, and is, possible to achieve this with the concept of mistake. Given that the articles of the PICC and of the PECL relating to mistake give relevance to assumptions of this kind - as long as they relate to facts or to law existing when the promise was made or the contract concluded - where the general conditions for avoidance based on mistake have been met $^{27}$, this notion of cause has to be discussed, in the light of a common law for Europe, only insofar as it also gives relevance to assumptions relating to the facts or the law as they arose after the conclusion of the contract. This is precisely the manner in which this concept is currently relevant in French law, owing to a very extensive interpretation of the term cause as meaning any decisive motive or purpose entertained by the parties 28 which has been frustrated or not been fulfilled. The concept of object is used there in a similar way, too.

\subsection{Validity to be determined at the time of concluding a contract.}

Apart from the question which assumptions can be considered relevant in this context, this problem can, in our view, not be regarded as a problem of validity. It is or a problem of (non-)performance or of restitution. Contemporary law shows a tendency to restrict

27 Cf. in particular Art. 3.4 and 3.5 PICC and 4:103 PECL.

28 On this development, cf. in particular G. GORLA, Il contratto $\S 22 \mathrm{c}$. 
invalidity in favour of application of the rules on performance and non-performance. We could formulate this modern rule of European common private law, we could as follows : "circumstances which arise after the time of concluding the contract cannot render a valid obligation or contract invalid, but can only lead to the application of the rules on performance or non-performance" (including implied terms, frustration, hardship). This rule cannot be found explicitly in the PECL or PICC, but is implicit in some of their other rules, e.g. the definition of "mistake" in the PICC and PECL ${ }^{29}$, or the rule in Article 3.7. PICC ${ }^{30}$. For this reason, it is is unfortunate that the CISG uses the term "avoidance" for certain circumstances where contracts are terminated (Cf. Art. 26, 49, 64, 81-84 CISG).

This rule implies that subsequent developments, which in some domestic legal systems are regarded as a reason for the discontinuation ("falling away") of the cause or object of the obligation or contract, can no longer be regarded as problems of validity. Whether this discontinuation will have retroactive effect or not will thus depend on the rules relating to the effects of termination or the effects of the fulfillment of a condition subsequent (cf. e.g. Art. 9:305 et seq. PECL) (or, insofar as they would play a separate role, the rules on restitution in general). On the other hand, the common rules on performance and nonperformance should sufficiently take into account the cases which are dealt with under the second function of cause in French law. I am not sure as to whether the proposed rules which have already do this sufficiently. Certainly, there are specific rules for cases where the performance becomes more onerous or less valuable, as is required under, for example, Article 6:111 PECL (Change of circumstances). But there may be cases of "frustration" or "assumptions" not met by them. Certainly, they could be regarded as implied terms on which the contract could be terminated or as defeasance clauses. But it would probably be good to have some more precise indications than just the idea of implied terms in general $^{31}$. The second part of $\S 812$ German BGB $^{32}$ - stemming from the roman condictio ob causam and condictio causa data, causa non secuta - does probably provide a good example.

Where circumstances which arise after the conclusion of a contract cannot render invalid a valid obligation or contract, the opposite is not necessarily the case. Invalid contracts can sometimes become valid retroactively by the subsequent fulfillment of a condition for their validity.

\subsection{Impossibility from the outset is not an invalidity}

29 Art. 3.4. PICC : "Mistake is an erroneous assumption relating to facts or law existing when the contract was concluded"; Art. 4:103 PECL "A party may avoid a contract for mistake of fact or law existing when the contract was concluded if ..."; compare Art. 6:228 (2) NBW and $\S$ 119 BGB et al.

30 "A party is not entitled to avoid the contract on the ground of mistake if the circumstances on which that party relies afford, or could have afforded, it a remedy for non-performance".

31 Art. 5.2 PICC and art. 6:102 PECL only speak about "implied obligations".

32 "(Wer auf kosten eines Anderen etwas erlangt, ist im zur Herausgabe verpflichtet) wenn der rechtliche Grund später wegfällt oder der mit einer Leistung nach dem Inhalte des Rechtsgeschäfts bezweckte rechtserfolg nich eintritt”. 
Viewed in the same light, a number of other problems which are present at the time of concluding the contract, whether known by the parties or not, do no necessarily lead to the obligation or contract being invalid.

This is the case where there is an impossibility of performance of an obligation from the outset (i.e. at the time of concluding the contract). In some legal systems, no obligation arises in such cases (in French cases sometimes because of "lack of object"). There is no reason why the fact that performance was already impossible at the time at which the contract was concluded should necessarily render the contract invalid, especially where the promisor was aware of this impossibility, or accepted the risk. On the contrary, many legal systems tend nowadays to consider any information relating to the object of the contract as a promise or a warranty, precisely in order to make a promisor contractually liable if the information he provided turns out to be incorrect. In many such cases, however, performance is impossible - for example, whenever the contract concerns a specific thing which lacks a quality which has been attributed to it. Such cases also fall within the scope of the concept of non-conformity of the goods as laid down in CISG. Although it is true that incorrect information should not invariably impose contractual liability (for full damages), and that in certain cases the promisor might be allowed to avoid the contract on grounds of mistake, this serves to demonstrate that in European private law :

"the mere fact that at the time of the conclusion of the contract the performance of the obligation assumed was impossible does not affect the validity of the contract"

(Art. 3.3 (1) PICC, a similar rule being laid down in Art. 4:102 PECL).

Certainly, it is possible that the conditions for avoidance for mistake are fulfilled, but the mere impossibility as such may not constitute an invalidity. In other words : possibility of performance is not a requirement for the validity of an obligation. However, it could be made a condition precedent, but there again, this is a question which concerns the determination of the contents of a contract.

\subsection{Unlawfulness from the outset.}

A similar principle must also apply where, at the time of the concluding the contract, one of the parties was not entitled to dispose of the assets to which the contract relates Article 3.3 (2) PICC expressly provides that this does not affect the validity of the contract, although this could be regarded as a form of unlawfulness from the outset. This rule thus lays down that unlawfuless (illegality or immorality) of performance from the outset does not necessarily affect the validity of the obligation or contract.

In a more general sense, it could be said that "relative unlawfulness" does not in itself render a contract invalid, "relative unlawfulness" being unlawfulness in relation to the person of the promisor or the debtor, which is not, however, "absolute" in the sense that no-one could lawfully perform the obligation. This rule follows from the generally accepted 
principle that performance by a third person is normally valid (e.g. Art. 7:106 PECL) ${ }^{33}$. It also covers those obligations whose performance could be unlawful under domestic law of one part of Europe, but lawful in other parts, if performance could validly take place in the latter. In all such cases, there is no problem of validity, but only a possible problem of (non-)performance.

It is more difficult to find a general rule on cases of "absolute" unlawfulness which exists at the moment at which the contract is concluded. The question should be dealt with more generally in the context of illegality and immorality.

\subsection{Abstraction of promises}

Another issue which deals with the notion of cause in the sense of an assumption on the part of the promisor, is the problem of "abstract" promises. This is not an issue concerning the validity of a promise or contract (although at times confused with it), but one which relates to the possibility of pleading certain defences (including the defences of nullity and avoidance), or the exclusion of such a possibility where "abstract" promises have been made. The question is not whether an "abstract" promise is valid, but in how far it is really "abstract". It is widely accepted nowadays that a defence cannot be excluded in the relationship between the parties which gave rise to it, or rather, that such an abstraction is only formal, i.e. a reversal of the burden of proof : qui petit quod statim redditurus est, dolo agit. On the other hand, it is accepted just as widely that the parties are free to exclude the use of certain defences in their relationship with third parties who are not deliberately acting in fraud of the debtor's rights. There are also different degrees of abstraction. This

problem is traditionally studied in the doctrine of contracts and thirs parties and therefore not elaborated here.

33 Comp. Art. 1236 French CC, § 267 BGB, Art. 6:30 NBW; R. ZIMMERMANN, The law of obligations, p. 752. 